УAK 330.341

\author{
K. Shatnenko, \\ $\mathrm{PhD}$ in Economics, senior lecturer, Odesa National Economic University \\ ORCID ID: 0000-0003-0139-7989 \\ I. Vyazmikina, \\ lecturer, Odesa National Economic University \\ ORCID ID: 0000-0001-8090-7072 \\ D. Maslov, \\ lecturer, Odesa National Economic University \\ ORCID ID: 0000-0002-1721-8319
}

DOI: $10.32702 / 2306-6792.2020 .7 .116$

\title{
SUBSTANTIAL RELATIONSHIP OF INDUSTRIAL AND FINANCE CAPITAL IN UKRAINE: PECULIARITIES
}

\author{
К. О. Шатненко, \\ к. е. н., старший викладач, Одеський національний економічний університет \\ I. А. Вязмікіна, \\ викладач, Одеський національний економічний університет \\ А. С. Маслов, \\ викладач, Одеський національний економічний університет
}

\section{СУБСТАНЦІЙНЕ ВІАНОШЕННЯ ПРОМИСАОВОГО І ФІНАНСОВОГО КАПІТААУ В УКРАЇНІ: ОСОБАИВОСТІ}

The paper deals with the problem of investment support for the development of industrial capital. It is shown that industrial capital operates on the basis of physically and morally obsolete fixed assets. Since industrial capital in Ukraine does not exist separately, but as an integral part of financial capital, it is the particularities of the functioning of financial capital that determines the statics and dynamics of industrial capital.

The paper explores the logic of financial capital development as an objective process. Financial capital, being a step in the development of capital in general, contains universal and particular features itself. Financial capital arises on the basis of the concentration of production in general, capitalist monopolies and joint-stock capital. Formally, all these features of financial capital are also present in Ukrainian financial capital, in reality - there is only a generic characteristic - concentration of production and capitalist monopoly. As for the jpint-stock form of capital, it remains undeveloped; relations in the management and transfer of property in large Ukrainian monopolies remain at the level preceding the industrial revolution. New companies also do not use shares as a tool for concentration and centralization of capital. The stock market as an essential feature of jointstock capital functioning is obscure and inaccessible to investors, which also indicates its underdevelopment and formal nature. On the other hand, there is a phenomenon of over-accumulation of loaned capital in the world, which is potentially a source for investment in Ukrainian industrial capital. The population within the country has also accumulated significant financial resources outside the banking system, which can be attracted for the development of industrial capital. The authors of the paper argue that the joint-stock capital can serve as a tool for turning these savings into investments. The development of not a formal, but real stock ownership, the development of the stock market in the direction of its greater transparency and accessibility for all investors can serve as a solution to the eternal problem of insufficient investment in Ukrainian industrial capital.

У статті розглядається проблема інвестиційного забезпечення розвитку промислового капіталу. Показано, що промисловий капітал в Україні функціонує на основі фізично і морально застарілих основних засобів. Оскільки промисловий капітал в Україні існує не відокремлено, а як складова частина фінансового капіталу, саме специфіка функціонування фінансового капіталу визначає статику і динаміку промислового капіталу.

У статті досліджується логіка розвитку фінансового капіталу як об'єктивного процесу. Фінансовий капітал, буАучи щаблем у розвитку капіталу взагалі, сам містить у собі загальні та особливі риси. Фінансовий капітал виникає на основі концентрації виробництва взагалі, капіталістичних монополій і акціонерного капіталу. Формально, ці всі риси фінансового капіталу присутні і в українському фінансовому капіталі, реально - Аля українського капіталу характерною є тільки родова ознака - концентрація виробництва і капіталістична монополія. Що стосується акціонерної форми капіталу, то вона залишається нерозвиненою, відносини з управління і передачі власності в великих українських монополіях залишаються на рівні, що передує промисловому перевороту. Нові підприємства так само не використовують акції як інструмент Аля концентрації і централізації власного капіталу. Фондовий ринок як суттєва риса функціонування акціонерного капіталу є непрозорим і малодоступним Аля інвесторів, що теж свідчить про його нерозвиненість і формальний характер. 3 іншого боку, в світі є явище перенагромадження позичкового капіталу, який потенційно є Ажерелом Аля інвестицій і в український промисловий капітал. У населення всередині країни також накопичено значні грошові ресурси поза банківською системою, які можуть бути залучені Аля потреб розвитку промислового капіталу. Автори статті стверджують, що інструментом перетворення таких заощаджень в інвес- 
тиції може служити акціонерна форма капіталу. Розвиток не формальної, а реальної акціонерної форми власності, розвиток фондового ринку в бік його більшої прозорості і доступності Аля всіх інвесторів може послужити рішенням Аля оАвічної проблеми недостатності інвестицій в український промисловий капітал.

Key words: industrial capital, finance capital, financial oligarcby, overaccumulation of capital, new industrialization, savings, investments.

Ключові слова: промисловий капітал, фінансовий капітал, фінансова олігархія, перенагромадження капіталу, нова індустріалізачія, заощадження, інвестичї̈.

\section{GENERAL PROBLEM STATEMENT}

The economic development of Ukraine was determined by highly monopolized industrial capital with dominant primary industry in the industrial structure, inefficient institutions, lack of incentives for innovative development. The reproduction of such industrial capital reinforces the economic backwardness that manifests itself in the low standard of living. Ukrainian scholars discuss the need for new industrialization, which could contribute to solving mentioned problems, at the same time the question about the sources of investments for industrialization at a new technological level remains unsolved.

\section{RECENT PUBLICATIONS REVIEW}

The challenges of modern economic development were uncovered by F. Tregenna [1], C. Perez [2], Yu. Kindzerskyi [3]. Industrial basis is presented as fundamental for economic development. At the same time the problems of Ukrainian industrial development make it clear that the reproduction of Ukrainian industrial capital means the reproduction of economic backwardness. That is why many scientists prove the idea of necessity of new industrialization [4]. The improvement of Ukrainian industrial capital can't be done without significant investments. There are many publications about different sources of investments for developing countries [5,6]. Although Ukraine can be considered as a developing country, the problem is in the lack of clear understanding of specific economic conditions of the economy of Ukraine.

The term "finance capital" as a special form of capital arising at the turn of the 19th and 20th centuries was proposed by R. Hilferding [7] and subsequently received refinement and development in the works of Soviet economists. The term "Financial capital" from the point of view of political economy it is reflected in the categories of money (loaned) and fictitious capital. The representatives of the mainstream economics interpret category of financial capital, while understanding of finance capital in its classical meaning is not the subject of their scientific interest due to differences in the goals and method of research. The concept of financial capital as a synonym for financial resources is usually used by researchers in the field of finance, enterprise finance, financial management, accounting, etc. in the works of L. Alekseyenko, A.M. Bilochenko, Yu.N. Vorobyev, V.G. Belolipetskiy, N.V. Drozd, V. Korneyeva, G.I. Khotinskaya, L.I. Chernikova and others. In a sense closer to the initial meaning of the category, finance capital is studied in the works of Ukrainian and Russian scientists: I. Levina, V.P. Leshchuk, A.V. Buzgalin, A.A. Zaletny, A.I. Kolganov, E.O. Mirgorodskaya, and in the works of foreign heterodox economists: J. Dumenil and D. Levy, D. Kotz, K. Lapavitsas, J. B. Foster, T. Norfield, D. Harvey, R. Pinto, B. Hawkey, F. Chaisnais et al.

A.V. Buzgalin and A.I. Kolganov saw in the overaccumulation of virtual financial capital a factor of exacerbation of economic crises [8, p. 412, 472]. They defined overaccumulation as an inability to apply capital with a profit. G. Arrighi considers capital overaccumulation as a factor of increasing competition, it leads to "the invasion of capitalist organizations in the activities of each other... losses of one organization are a condition for profit of another" [9, p. 296]. D. Harvey views the crisis of the 1970s as a crisis of capital overaccumulation [10, p. 23]. A.M. Markaryan considers financial capital overaccumulation as the main fundamental cause of the 2007 crisis [11, p. 157].

\section{PREVIOUSLY UNRESOLVED PART OF GENERAL PROBLEM}

The mechanism of industrialization is connected with the prerequisites that encourage the renovation of industrial capital: a decrease in the rate of return on investment, the emergence of radical innovations that can increase productivity, and a sufficient amount of investment to implement them. Thus, a specific question about the sources of investments becomes vital.

Scientists often indicate the sources of possible investments, but the capabilities for attracting them in Ukraine are limited, because of specifics in the formation of the finance capital and the finance oligarchy. Their economic interests enter in conflict with the interests of national industrial capital development. On the other side there are evidences of overaccumulation of loaned capital 
Table 1. The level of fixed assets depreciation by type of economic activity in 2000-2018, \%

\begin{tabular}{|l|l|l|l|l|l|l|l|l|l|}
\hline $\begin{array}{c}\text { Types of } \\
\text { economic activity }\end{array}$ & $\mathbf{2 0 1 0}$ & $\mathbf{2 0 1 1}$ & $\mathbf{2 0 1 2}$ & $\mathbf{2 0 1 3}$ & $\mathbf{2 0 1 4}$ & $\mathbf{2 0 1 5}$ & $\mathbf{2 0 1 6}$ & $\mathbf{2 0 1 7}$ & $\mathbf{2 0 1 8}$ \\
\hline $\begin{array}{l}\text { Agriculture, } \\
\text { hunting, forestry }\end{array}$ & 40,8 & 32,6 & 34,6 & 35,8 & 38,8 & 38,9 & 37,3 & 35,7 & 35,4 \\
\hline Primary industry & 47,8 & 56,3 & 54,1 & 57,1 & 65,3 & 57,9 & 54,6 & 47,2 & 43,1 \\
\hline $\begin{array}{l}\text { Processing } \\
\text { industry }\end{array}$ & 66,8 & 56,8 & 57,2 & 50,1 & 56,9 & 75,8 & 76,4 & 64,6 & 64,3 \\
\hline Construction & 50,1 & 58,8 & 55,1 & 51,9 & 54,4 & 53,6 & 36,0 & 45,7 & 44,5 \\
\hline $\begin{array}{l}\text { Transport and } \\
\text { communications }\end{array}$ & 94,4 & 95,6 & 96,0 & 96,7 & 97,9 & 51,7 & 50,6 & 47,6 & 62,9 \\
\hline
\end{tabular}

Source: [12].

in the world scale which could be attracted to the Ukrainian economy.

\section{OBJECTIVE}

The authors aim to study the peculiarity of Ukrainian finance capital and financial oligarchy in its relation to industrial capital and, on this basis, to propose a tool for attracting investment into the country's economy.

\section{MAIN RESEARCH MATERIAL OUTLINE}

There are numerous studies proving that the objective mechanism for the national industrial capital renovation doesn't exist. This fact is reflected in the low levels of labor productivity. Regarding the nature of new technologies diffusion, it occurs from the center (developed countries) to the periphery (underdeveloped countries). Therefore, we can assume that the technological structure of Ukrainian industrial capital should be characterized by technologies of the latest or almost latest generations. Nevertheless, low productivity compared to other countries indicates a high level of technological backwardness. For example, revising the level of fixed assets depreciation by type of economic activity (Table 1 ), we can see a rather high level of depreciation of fixed assets in different industries including primary and processing industries, transport and communications.

To analyze the technological development of industrial capital it is necessary to determine the indicators of fixed assets use efficiency. For the better understanding of the latest tendencies, the period from 2010 to 2018 was chosen (Table 2). The return on assets shows a decline in the productivity of fixed assets in different industries.

Thus, it can be argued that the level of depreciation and the fixed assets use efficiency confirm the need for a fixed capital renovation. Further capital reproduction based on obsolete and physically deteriorated fixed assets condemns the economy to slow growth and, given the global tendency to accelerate the implementation of innovations, to a constantly widening gap with the developed countries.

The low rates of renovation of fixed assets can also be explained by the existing structure of the economy, which does not require high rates of innovations' introduction, since it is characterized by a technological mode of production based on a low level of technological development. That is why the problem of structural change towards the increased share of high-productivity industries appears. The purpose of this change is to provide the structure of industries which is characterized by the dynamic technological development. It will make it reasonable to implement innovations. This is highly important for sustainable development.

At first, it is important to make technological renovation of industrial capital. Weak development of Ukrainian machinery can't provide domestic industry with needed equipment. Moreover, it should be the highly productive equipment. Since it is impossible to find all the needed technologies on the national market, this problem can be solved by attracting them from the abroad.

Therefore, there is a problem to provide the method of such attraction. The analysis of developing countries' experience has shown that we can distinguish the following methods: to purchase new technologies from export proceeds, as well as to attract TNC capital, which will use advanced technologies through its branches. The possibilities of using these methods can be analyzed on the basis of the balance of payments of Ukraine (Table 3). Foreign exchange earnings from current transfers, exports of goods and services can be used to acquire new technologies from abroad. For the formation of these resources the value of current

Table 2. Return on assets by different types of economic activity in 2010-2018

\begin{tabular}{|l|l|l|l|l|l|l|l|l|l|}
\hline \multicolumn{1}{|c|}{$\begin{array}{c}\text { Types of economic } \\
\text { activity }\end{array}$} & $\mathbf{2 0 1 0}$ & $\mathbf{2 0 1 1}$ & $\mathbf{2 0 1 2}$ & $\mathbf{2 0 1 3}$ & $\mathbf{2 0 1 4}$ & $\mathbf{2 0 1 5}$ & $\mathbf{2 0 1 6}$ & $\mathbf{2 0 1 7}$ & $\mathbf{2 0 1 8}$ \\
\hline $\begin{array}{l}\text { Agriculture, hunting, } \\
\text { forestry }\end{array}$ & 1,67 & 2,15 & 1,90 & 1,97 & 2,22 & 2,66 & 2,42 & 1,53 & 1,51 \\
\hline Primary industry & 0,84 & 0,76 & 0,66 & 0,50 & 0,43 & 0,49 & 0,62 & 0,85 & 1,03 \\
\hline Processing industry & 1,12 & 1,47 & 1,41 & 1,47 & 1,29 & 0,73 & 0,81 & 1,52 & 1,61 \\
\hline $\begin{array}{l}\text { Electricity, gas and water } \\
\text { production and } \\
\text { distribution }\end{array}$ & 0,37 & 0,46 & 0,20 & 0,17 & 0,20 & 0,10 & 0,30 & 0,38 & 0,22 \\
\hline Construction & 2,10 & 2,44 & 2,36 & 2,02 & 2,53 & 3,04 & 3,30 & 2,92 & 3,08 \\
\hline $\begin{array}{l}\text { Transport and } \\
\text { communication activities }\end{array}$ & 0,04 & 0,04 & 0,04 & 0,03 & 0,02 & 0,21 & 0,22 & 0,35 & 0,29 \\
\hline
\end{tabular}

Source: calculated based on [12]. 
Table 3. Balance of Payments of Ukraine in 2010-2018

\begin{tabular}{|l|r|r|r|r|r|r|r|r|r|}
\hline \multicolumn{1}{|c|}{ Indicator } & $\mathbf{2 0 1 0}$ & $\mathbf{2 0 1 1}$ & $\mathbf{2 0 1 2}$ & $\mathbf{2 0 1 3}$ & $\mathbf{2 0 1 4}$ & $\mathbf{2 0 1 5}$ & $\mathbf{2 0 1 6}$ & $\mathbf{2 0 1 7}$ & $\mathbf{2 0 1 8}$ \\
\hline $\begin{array}{l}\text { Current account, } \\
\text { million U.S. dollars }\end{array}$ & -3016 & -10233 & -14335 & -16518 & -4596 & 1616 & -1340 & -2442 & -4367 \\
\hline $\begin{array}{l}\text { Net lending (+)/ Net } \\
\text { borrowing (-), } \\
\text { million U.S. dollars }\end{array}$ & -2828 & -10132 & -14295 & -16578 & -4196 & 2072 & -1248 & -2446 & -4330 \\
\hline $\begin{array}{l}\text { Foreign direct } \\
\text { investments (net), } \\
\text { million U.S. dollars }\end{array}$ & -5759 & -7015 & -7195 & -4079 & -299 & -3012 & -3268 & -2593 & -2360 \\
\hline
\end{tabular}

Source: [13].

account should be positive. As we can see, since 2010 it was positive only in 2015 , so there is a shortage of foreign exchange earnings.

Moreover, the capital account is characterized by the constant presence of net borrowing, which indicates that the country is a debtor, and therefore needs funds to service external obligations. As for foreign direct investment, the negative balance of this account indicates that there is an outflow of capital. Thus, there is no reason to claim that we have enough financial resources in the country for the import of innovative technologies.

The problem of financing the renovation of industrial capital has always been at the center of scientific discussions. So, for developed countries, the mechanism of such renovation is explained by the Keynesian theory. The main idea of it is in transferring savings to investments. There are a lot of recommendations to Ukrainian economic policy which assume that this mechanism works in Ukrainian economy. However, such mechanism in countries with weak development of capitalist relations is either absent or incapable to make any significant impact. First of all, there is the lack of an adequate amount of savings due to the low income level of the majority of the population, and there is the tendency to conspicuous consumption of highincome people. Moreover, the determining factor is the low quality of the institutions necessary for the functioning of the mechanism itself. For example, the volume of deposits by households is an important potential source for investment (Table 4). For the period 2010-2018 there has been an increase in deposits. However, it should be borne in mind that such dynamics may be due to an attempt to protect savings from depreciation due to the high level of inflation. The average level of total bank deposits in relation to GDP for the world is around $50 \%$, while for Ukraine it is only $28 \%$ [14].

An indicator that reflects the actual possibility of using the savings of the households for investments to renovate fixed assets is the long-term deposits. So, for the period 2010-2018 there is a negative tendency of deposits over 2 years. Thus, an increase in deposits and a simultaneous reduction in the share of long-term deposits indicate an increase in distrust to the Ukrainian financial system. The amount of savings in the economy remains low, and interest rates are too high to use it as a potential source of investments. At the same time, there are studies that claim significant accumulations of cash from the population outside bank system [15, p. 12; 16].

This situation can be explained by the specifics of the formation of industrial capital in Ukraine. As a result of the privatization in the 1990s, a financial oligarchy was formed in the Ukrainian economy, but not in its classical form. Since the productive form of Ukrainian industrial capital was highly developed and represented by the large monopolies, the new private owners of the former state enterprises turned not just into capitalists, but into monopolists. These monopolies were not created naturally from competition. They were formed artificially. It was the artificial process of the formation of such monopolies that determined their specifics, as well as the specifics of Ukrainian finance capital - the joint-stock capital was not typical for it. The jointstock capital as a tool for capital formation and merger was never needed in the Soviet economy.

Finance capital: universal and particular

The classical finance capital as a special form of capital appears at the turn of the 19th-20th

Table 4. Deposits by households held within deposit-taking corporations in 2010-2018

\begin{tabular}{|l|l|l|l|r|r|r|r|r|r|}
\hline \multicolumn{1}{|c|}{ Indicator } & $\mathbf{2 0 1 0}$ & $\mathbf{2 0 1 1}$ & $\mathbf{2 0 1 2}$ & $\mathbf{2 0 1 3}$ & $\mathbf{2 0 1 4}$ & $\mathbf{2 0 1 5}$ & $\mathbf{2 0 1 6}$ & $\mathbf{2 0 1 7}$ & $\mathbf{2 0 1 8}$ \\
\hline $\begin{array}{l}\text { Total, millions of } \\
\text { hryvnias }\end{array}$ & 275093 & 310390 & 369264 & 441951 & 418135 & 410895 & 444676 & 495313 & 530250 \\
\hline $\begin{array}{l}\text { including deposits } \\
\text { over 2 years, } \\
\text { millions of } \\
\text { hryvnias }\end{array}$ & 17025 & 21206 & 27062 & 14580 & 14577 & 15801 & 5382 & 6227 & 6757 \\
\hline $\begin{array}{l}\text { The share of } \\
\text { deposits over } \\
2 \text { years, \% }\end{array}$ & 6,19 & 6,83 & 7,33 & 3,30 & 3,49 & 3,85 & 1,21 & 1,26 & 1,27 \\
\hline
\end{tabular}

Source: [13] 
centuries, marking the transformation of the "perfect competition" era into "monopoly capitalism". The dialectics of universal and particular in the era of monopoly capitalism is studied in detail in the monograph by Kasenov [17], where the author proposes to consider the concentration of production in general as the starting point to study monopoly capitalism. Indeed, "concentration of production in general" is that initial "grain" from which the general - capitalist monopolies - subsequently develops. Of course, monopoly becomes "universal" at a certain stage of the capitalism development, as the richest universal category reflecting its essence, embodying all relatively independent particular features of this era. In relation to the categories of "value" - a universal characteristic of commodity production in general, and "surplus value", which is general to the capitalist mode of production and the era of free competition, "monopoly" appears as the specific.

The concentration of production and capital at the extreme stage of development of free competition, first manifests itself as a single, in individual industries, as the "barely noticeable embryos" of the new system: $60-70$ s of the XIX century - the highest, ultimate level of development of free competition. Monopolies are only barely visible embryos. After the crisis of 1873, cartels spread more and more to all sectors, but they still were an exception, they still were a transient phenomenon. At the beginning of the XX century - "cartels become one of the foundations of the whole economic life" - the capitalism of free competition turns into monopoly capitalism [18, p. 20].

The monopoly, having become universal, irreversibly changes the face of the capitalist system: the law of surplus value in the era of free competition manifests itself more or less evenly through the law of the average rate of profit, however, in the era of the domination of monopolies, the capital flow among industries becomes difficult and this law manifests itself unevenly in the form of the law of monopolistic profit. Thus, it is no longer the law of average profit that regulates the proportions of the distribution of resources between industries, but the law of monopolistic profit.

In this sense monopoly, at first as a single, separate in its historical development through a particular, becomes a general, universal law that determines the further dynamics of capitalism development. Monopoly exists along with free competition increasingly exacerbating the contradictions inherent in commodity production in general and capitalist commodity production in particular. Known long before monopoly capita- lism as a single, separate phenomenon, the jointstock form of capital by the end of the XIX century becomes ubiquitous, on the one hand - as the result of the capitalist credit relations development (the source of it is an idle money accumulated as a result of the concentration of production and capital), and on the other hand, the joint-stock form itself becomes a powerful catalyst for the processes of concentration and centralization of capital and concentration of production.

Only when the capitalist monopoly becomes the dominant force, the joint-stock form of capital becomes the main form of organization of large capitalist enterprises, bringing changes to the property relations.

An important point here is the dual nature of a share, which on the one hand is the "title" of ownership of the means of production, and on the other, the claim to a certain part of the annual income in the form of a dividend, the last, as shown by Hilferding, ultimately is reduced to the interest with the development of the capital market [7, p. 109]. However, to execute one's right of ownership for the means of production, it is necessary to concentrate a significant part of shares in one hand (previously half of all shares were required, but over time, a much smaller part of them became sufficient to provide control over the entire real capital of the joint-stock company).

Through the development of credit relations, the boundary of growth in the scale of production, not limited by the size of individual capital, is removed. The advantages of joint-stock companies over individual capitals and their logical victory are sufficiently disclosed by Hilferding [7, p. 147].

All subsequent features of the monopoly stage of capitalism grow out of the original "grain" the concentration of production in general. The concentration of production in general in objective reality is represented by particular forms of monopolistic associations in industry, which gives rise to the need to spread the tendency towards monopolization in banking. Based on the concentration of production, banking monopolies are formed after industrial ones. The universal, having completely mastered one economic feature of monopoly capitalism - the formation and domination of monopolies in production "captures" a new, special form of development of monopoly capitalism relations. The development of banks from intermediaries into omnipotent monopolists that centralize capital and money income of a significant part of society is the result of banking concentration.

Joint-stock ownership also extends to banks, that, among other things, provides an opportunity 
to significantly reduce the equity share. Today, for example, the excess of bank assets over equity by 20 times became normal thing [19, p. 319].

In the course of its development, the distinguished features of monopoly capitalism - the concentration and formation of monopolies in industry and the concentration and formation of monopolies in banking, which comprise separate, independent aspects of the universal - pursuit of an interest to obtain monopolistic profits, merge into new form of capital - finance capital. Due to the discovered dual nature of a share, the merger of the capitals of banking and industrial monopolies becomes much easier and takes on a relatively stable form - the form of financial or financial-industrial groups (FIGs).

Large corporations' shares dispersal creates the basis for the effective concentration of control by the financial oligarchy over large masses of social capital in both production and circulation. Without a developed relationship of credit and fictitious capital, the mechanism of power of the financial oligarchy could not be realized. Indeed, after all, "merging" of capital means the concentration of controlling blocks of shares of both large industrial monopolies and large banks in the hands of financial magnates.

Back in the 80 s of the last century, researchers noted that an increasing part of the fictitious capital that belonged to the corporations having operates in the real sector of economy was concentrated in the financial institutions through the purchase of shares on the stock market.

In Ukraine the mechanism of finance capital domination has its peculiarities. The power of financial oligarchy is not connected to stock market capitalization of their enterprises as soon as, in fact, free purchase and sale of shares is not developed. The oligarchs exercise their power by resorting to informal relations - corruption and lobbying. The lack of real competition in the purchase and sale of shares of large monopolies puts restrictions on the formation of competing owners who would exercise control over the activities and economic efficiency of Ukrainian corporations. Since monopoly capital exists in the form of finance capital, and the latter needs developed elements of the financial system to mobilize, accumulate and circulate, the monopolization and "financialization" of capitalism are two sides of the same process of transforming capitalism of free competition into monopoly capitalism.

Since there was never free competitive capitalism in the Ukrainian Soviet Republic, but the level of productive forces development corresponded to the stage of monopoly capitalism, after independence, market reforms should not have been aimed at renewing a free competition (which is possible only if the capital of monopolies is destroyed), but rather creating new forms of competition that were consistent with monopoly capitalism. One of the directions of such reforms may be the creation of a real stock market. This issue is ignored by the subjects of economic policy precisely because it is outside the interests of oligarchic groups. Transparent stock market could help to attract foreign investments and savings of residents kept out of bank system of Ukraine. The overaccumulated loaned capital in the world can serve as a source for foreign investments.

To explain loaned capital overaccumulation phenomenon the "excess" savings concept by J. Robinson can be used. "If the ratio of saving which the capitalists (taken together) choose to make exceeds the rate of accumulation dictated by technical progress, the excess savings can only be 'capitalized' if there is an outlet for investment outside the system" [20, p. 25]. Keynesian economic theory states that as income grows, savings grow relatively faster than income; this is a characteristic of the marginal propensity to save (MPS), which is calculated by dividing the change in savings by the change in income.

It follows that, as the economy grows, savings will grow at an accelerated pace, thus increasing the "excess" savings, which is reflected in the growth of loaned capital. Formation of "excess" savings leads to complication of sales of manufactured goods. "Outside the system" investment outlet, which J. Robinson refers to, does not necessarily mean outlet to another country. It may also occur outside the income structure that has been generated within the system, that is, through debt. Debt thus becomes a form of export of capital, but not outside the country, but outside the existing income structure.

Debt allows to increase the consumption of debtors by changing the structure of real consumption in the country. The excess of capital, value in monetary form, first arises from existing proportions of reproduction. Further, this redistribution changes the proportions of social reproduction and becomes a condition for reproduction in new proportions.

But since a loan is given on principals of term, repayment and interests payment, the loaned capital must be repaid back with interest, which further increases the "excess" savings, for which their owner could not find a productive use. Thus, it leads to a long-term accumulation of "excess" savings, which are not used in the real economy, 
but nevertheless are looking for a profitable use. Such savings form and increase the excess amount of loaned capital that is reflected in the growth of bank deposits (fig. 1).

The overaccumulation of loaned capital is also reflected in the growth of stock market capitalization (fig. 2).

Overaccumulation of loaned capital indicates an excess of idle funds owned by those entities that doesn't find an application for these funds in form of "capital as a function" in sectors of the economy they came from. This is not surprising because, due to the development of production, scientific and technological progress, the structure of consumption is constantly changing, but the structure of mass production can't change at the same pace in the same proportion as the structure of consumption.

Credit as a form of value movement serves as an accelerator of the economy restructuring, but value movement in the form of credit is carried out on the principles of term, repayment and interest's payment, since these principles allow the owner of value to increase it. Credit principles force redistributed value to move back from the borrower to the lender, but the income that the borrower receives in the form of "profit of enterprise" allows him to repay the loan (if his affairs are successful) without reducing his capital by the entire amount of the loan.

Thus, the industry where the borrower operates, which need an additional capital, receives it, and on this side the structure of production will be changed. But what about the excess of value received by the lender? The excess value will not decrease, but, on the contrary, it will increase by the amount of an interest withheld from the borrower. Thus, a steady increase in the volume of loaned capital, which seeks the possibility of its application for self-growth is inevitable. With the development of social production, the tendency to increment of the accumulation of loaned capital should increase.

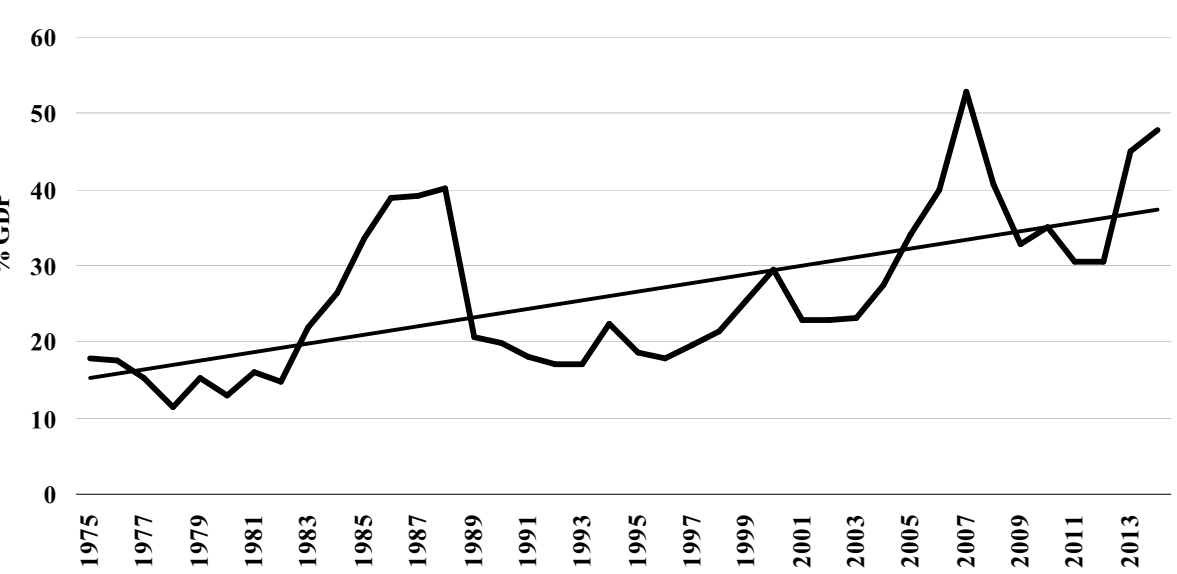

Fig. 2. Stock market capitalization to the world GDP (\%) [14]
Today, the Ukrainian economy uses the overaccumulated loaned capital only for the government borrowing, that is, not for investment, but for consumption, and the possibility of using excess domestic and foreign savings for the development of industrial capital remains unfulfilled.

The current situation of the financial market development can be estimated by the structure of the stock market contracts with distribution by financial instruments (Table 5).

As we can see, the largest share of operations on the stock exchange belongs to the government bonds.

In 2018 the volume of issued shares reached its minimum for the past five years (UAH 22.28 billion). The main issuers of shares were banks that carried out emissions for the purpose of additional capitalization [21, p. 13]. These data shows that the Ukrainian stock exchange doesn't give significant support to Ukrainian industrial capital. Thus, the instruments for transformation of savings into investments that are effective in developed economies are not really as effective in Ukrainian economy. 
АГРОСВIT № 7, 2020

\section{CONCLUSIONS AND PERSPECTIVES \\ FOR FUTURE RESEARCH}

The need for investment into the industrial capital of Ukraine is due to its substance. Without investments, capital cannot fulfill its main function - to grow, therefore, it ceases to be capital. Since the modern Ukrainian banking system cannot fulfill the function of ensuring the transformation of savings into investments, the source of investments in Ukrainian industrial capital may be the savings of non-residents, which are in excess due to the overaccumulation of loaned capital in the world, as well as the savings of Ukrainians kept outside the banking system. Joint-stock form of capital could serve as a tool for turning these savings into investments. Although Ukrainian finance capital has a common generic characteristic with finance capital in general - it is formed on the basis of concentration of production, its peculiarity is that the joint-stock form of capital actually played an insignificant role for the creation and merger of Ukrainian monopolies in the banking sector, industry and trade. Nevertheless, not formal, but real development of the stock ownership and stock market in the direction of its greater transparency and accessibility for all investors could serve as a solution to the eternal problem of insufficient investment in Ukrainian industrial capital, at the same time economic interests of financial oligarchy controlling industrial capital come into conflicts with the need for renovation of industrial capital in a new technological base.

\section{$\Lambda$ iтература:}

1. Tregenna F. Deindustrialisation, structural change and sustainable economic growth. United Nations University: MERIT, 2015.61 p.

2. Перез К. Технологические революции и финансовый капитал: Аинамика пузырей и периодов процветания. Москва:Аело, 2011. 232 с.

3. Кіндзерський Ю. Аеіндустріалізація та іiі детермінанти у світі. Економіка України. 2017. № 11 . С. $48-72$.

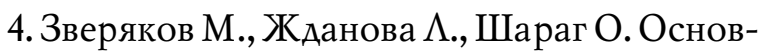
ний капітал у парадигмі нової індустріалізації. Одеса: Астропринт, 2019. 204 с.

5. Колупаєв Ю., Залубовська С., Мельничук I. Проблеми залучення інвестиційних ресурсів в економіку України. Інвестиції: практика та досвід. 2018. № 8, С. 26-29.

6. Lautier M. Domestic investment and FDI in developing countries: the missing link. Journal of economic development. 2012. № 37 (3), P. 1-23.
7. Гильфердинг Р. Финансовый капитал. Исследование новейшей фазы развития капитализма. Москва: Издательство социальноэкономической литературы, 1959. 492 с.

8. Бузгалин А., Колганов А. Пределы капитала: методология и онтология. Реактуализация классической философии и политической экономии. Москва: Культурная революция, $2009.680 \mathrm{c}$.

9. Арриги Аж. Аолгий двадцатый век; Аеньги, власть и истоки нашего времени. Москва: Издательский дом "Территория будущего", 2006. 472 c.

10. Харви А. Краткая история неолиберализма. Актуальное прочтение. Москва: Поколение, 2007. 288 с.

11. Маркарян А. Анализ природы современного долгого кризиса сквозь призму марксистской концепции экономических циклов. Научные труды Вольного экономического общества России. 2013. № 174. С. 151-159.

12. Сайт Аержавної служби статистики України. URL: http://www.ukrstat.gov.ua

13. Сайт Національного Банку України. bank.gov.ua. URL: https://bank.gov.ua/statistic.

14. Site of the World Bank. Global Financial Development Database. www.worldbank.org. Retrieved from http://www.worldbank.org/en/ publication/gfdr/data/global-financial-development-database

15. Жолудь О. Піонтківська І. Аоларизація та чорний ринок валюти в Україні: причини, обсяги, наслідки для економіки та політики. Київ: Центр економічної стратегії, 2016. 19 c.

16. Сайт "Ukraine Economic Outlook". http:/ /ua-outlook.com.ua. URL: http://ua-outlook.com.ua/ru/2019/12/13/2019-forecasts-reports

17. Касенов Б. Аиалектика всеобщего, особенного и единичного в экономических трудах К. Маркса и В.И. Аенина. Алма-Ата: Наука, $1971.363 \mathrm{c.}$.

18. Иенин В.И. Империализм как высшая стадия капитализма. Москва: Издательство политической литературы, 1989. 125 с. 
19. Norfield T. The City. London and Global Power of Finance. London: Verso, 2016. 288 p.

20. Robinson J. Introduction. The Accumulation of Capital by Rosa Luxemburg. London, 1951. pp. 13-28.

21. Сайт Національної комісії з цінних паперів та фондового ринку. Річний звіт Національної комісії з цінних паперів та фондового ринку за 2018 рік. www.nssmc.gov.ua. URL: https://www.nssmc.gov.ua/wp-content/uploads/ 2019/08/zvit_2018.pdf

\section{References:}

1. Tregenna, F. (2015), Deindustrialisation, structural change and sustainable economic growth, MERIT Working Papers 032, United Nations University - Maastricht Economic and Social Research Institute on Innovation and Technology, Maastricht, Netherlands.

2. Perez, C. (2011), Tehnologicheskie revolyucii i finansovyj kapital: Dinamika puzyrej i periodov procvetaniya [Technological Revolutions and Financial Capital: The Dynamics of Bubbles and Golden Ages], Delo, Moscow, Russia.

3. Kindzerskyi, Yu. (2017), "Deindustrialization and its determinants in the world and in Ukraine", Ekonomika Ukrainy, vol. 11, pp. 48-72.

4. Zveryakov, M. Zhdanova, L. and Sharah, E. (2019), Osnovnyi kapital u paradyhmi novoi industrializatsii: vidtvoriuvalnyi aspekt [Fixed capital in the paradigm of the new industrialization: the reproduction aspect], Astroprint, Odesa, Ukraine.

5. Kolupayev, Yu. Zalyubovska, S. and Melnichuk, I. (2018), "The problems of attraction investment resources into the economy of Ukraine", Investytsii: praktyka ta dosvid, vol. 8, pp. 26-29.

6. Lautier, M. (2012), "Domestic investment and FDI in developing countries: the missing link", Journal of economic development, vol. 37, no. 3, pp. 1-23.

7. Hilferding, R. (1959), Finansovyj kapital. Issledovanie novejshej fazy razvitiya kapitalizma [Finance Capital. A Study of the Latest Phase of Capitalist Development], Izdatelstvo socialnoekonomicheskoj literatury, Moscow, USSR.

8. Buzgalin, A. V. and Kolganov, A. I. (2009), Predely kapitala: metodologiya i ontologiya. Reaktualizaciya klassicheskoj filosofii i politicheskoj ekonomii [The limits of capital: methodology and ontology. The Reactualization of Classical Philosophy and Political Economy], Kulturnaya revolyuciya, Moscow, Russian Federation.

9. Arrigi, G. (2006), Dolgij dvadcatyj vek: Dengi, vlast $\mathrm{i}$ istoki nashego vremeni [The Long Twentieth Century: Money, Power, and the Ori- gins of Our Times], Izdatelskij dom "Territoriya budushego", Moscow, Russian Federation.

10. Harvey, D. (2007), Kratkaya istoriya neoliberalizma. Aktualnoe prochtenie [A Brief History of Neoliberalism], Pokolenie, Moscow, Russian Federation.

11. Markaryan, A. M. (2013), "Analysis of the nature of the modern debt crisis through the prism of the Marxist concept of economic cycles", Nauchnye trudy Volnogo ekonomicheskogo obshestva Rossii - Scientific works of the Free Economic Society of Russia, vol. 174, pp. 151-159.

12. The official site of the State Statistics Service of Ukraine (2020), available at: http:// www.ukrstat.gov.ua (Accessed 10 March 2020).

13. The official site of the National Bank of Ukraine (2019), available at: https://bank.gov.ua/ statistic (Accessed 26 December 2019).

14. The site of World Bank (2019), "Global Financial Development Database", available at: http://www.worldbank.org/en/publication/gfdr/ data/global-financial-development-database (Accessed 20 December 2019).

15. Zholud, O. and Piontkivska, I. (2016), Dolaryzatsiia ta chornyi rynok valiuty v Ukraini: prychyny, obsiahy, naslidky dlia ekonomiky ta polityky [Dollarisation and the currency black market in Ukraine: reasons, volumes, consequences for economy and policy], Centre for Economic Strategy, Kyiv, Ukraine.

16. The site of Ukraine Economic Outlook (2019), "Macroeconomic forecast of Ukraine Economic Outlook for 2020", available at: http:// ua-outlook.com.ua/ru/2019/12/13/2019-forecasts-reports/ (Accessed 20 December 2019).

17. Kasenov, B. (1971), Dialektika vseobshego, osobennogo i edinichnogo v ekonomicheskih trudah K. Marksa i V.I.Lenina [The dialectics of the universal, particular and singular in the economic works of $\mathrm{K}$. Marx and V. I. Lenin], Nauka, Alma-Ata, USSR.

18. Lenin, V. I. (1989), Imperializm, kak vysshaya stadiya kapitalizma [Imperialism, the Highest Stage of Capitalism], Izdatelstvo politicheskoj literatury, Moscow, USSR.

19. Norfield, T. (2016), The City. London and Global Power of Finance, Verso, London, UK.

20. Robinson, J. (1951), Introduction. The Accumulation of Capital by Rosa Luxemburg, London, UK.

21. The official site of National Securities and Stock Market Commission (2019), "The annual activity report of the National Securities and Stock Market Commission in 2018", available at: https:/ /www.nssmc.gov.ua/wp-content/uploads/2019/ 08/zvit_2018.pdf (Accessed 20 December 2019). Стаття надійщла до редакиії 31.03.2020 p. 